\title{
Systematic Review: The Impact of Pedagogy on Equity in Science Education in Rural Schools
}

\author{
Justin Tukau Jalak, Nurfaradilla Mohamad Nasri \\ Faculty of Education, University Kebangsaan Malaysia, Selangor, Malaysia \\ Email: justintukau4051@gmail.com
}

How to cite this paper: Jalak, J. T., \& Nasri, N. M. (2019). Systematic Review: The Impact of Pedagogy on Equity in Science Education in Rural Schools. Creative Education, 10, 3243-3254.

https://doi.org/10.4236/ce.2019.1012248

Received: October 21, 2019

Accepted: November 27, 2019

Published: November 30, 2019

Copyright $\odot 2019$ by author(s) and Scientific Research Publishing Inc. This work is licensed under the Creative Commons Attribution International License (CC BY 4.0).

http://creativecommons.org/licenses/by/4.0/ (c) (i) Open Access

\begin{abstract}
The pedagogical impact on equity in science education is an interesting issue to be studied because it gives an overview of the delivery of science education to the community. The concept of equity in science education requires people to have equal rights for quality science education regardless of their geographical location, gender, and socio-economic factors. Systematic review was used to gather empirical studies on pedagogical issues related to science education. Systematic reading was done via databases such as Google Scholar, ERIC and SAGE. The articles were then filtered using PRISMA 2009 Flow Diagram before they went through another filtering process using the six elements in research that adapted from McDermott et al. (2004). Systematic research has found that teacher pedagogy influences the concept of equity in science education in rural schools. The previous studies found there is still a gap in rural school science education to meet science education standards. However, teachers and students are still positive in science learning because the effectiveness of science education depends on the wisdom of teachers in choosing teaching strategies.
\end{abstract}

\section{Keywords}

Issues, Impacts Pedagogy, Equity, Science Education

\section{Introduction}

Science education is a field resulted from human effort to find a rational explanation of nature phenomenon (Kementerian Pendidikan Malaysia, 2015). According to Cooper (2015), science is the development of explanatory theory that helps us organize our understanding and make predictions about the world. Holbrook (2010) states that science education can help to provide students who can shape the world they live in. Therefore, there is a need to study science in schools. One of the goals set by the Organisation for Economic Co-operation 
and Development (OECD, 2012) is to require all students to have equal opportunities to study science and it expects all students to meet high academic standards in education. This aspect is interrelated to equity in science education. According to Dewan (2005), equity is defined as equal ownership in an organization. It thus means fairness. Equity in education refers to an educational system that provides quality education to all regardless of the geographical factor, gender or socioeconomic background. To achieve this, teachers' pedagogy is of paramount importance. Pedagogy includes various aspects such as teaching style, feedback, evaluation, teaching theory and how the teacher delivers curriculum content during teaching and learning sessions (Good \& Lavigne, 2017). Blatchford et al. (2006), on the other hand, relates pedagogy with a teaching technique and strategy that enables learning to happen and is directly an interactive process between teachers and students. Thus, this study conducted an empirical systematic reading to investigating to extent pedagogical affect equity in science education at rural schools.

\section{Background of the Study}

The factor that led to this research proposal was the admiration of Japanese researchers' success in science education which is reflected in their performance at TIMSS and PISA. Education in Japan put a great emphasis on equity in education and every student in Japan is given ample opportunity to learn science. Meanwhile, in the Programme for International Students Assessment (PISA) 2015 report on student achievement in science and attitudes toward science, Singapore outperformed high-performing OECD countries such as Japan, Estonia, Finland, and Canada. This shows that neighboring countries like Singapore, which have a culture and language similar to Malaysia, can stand out in international science education (OECD, 2018). The success of Singaporean students is fueled by the attitude of Singaporean students who have always enjoyment of science, preference for science careers, and appreciation of the social implications of science (Caleon \& Subramaniam, 2008). Continuation of the PISA 2015 report, the government plans to bridge the achievement gap between rural and urban schools to ensure Malaysian children have equal access to education (Malaysian Blueprint 2013-2025). The success of today's education can be a springboard to determine the plan. Education is seen as a way to develop human capital and improve the standard of living (Rashid, 2008).

\section{Objective}

The study aims to identify whether pedagogy in science education in rural schools is equal and fulfill the equity concept. Thus systematic review was done to achieve these objectives.

\section{Research Question}

- To what extent a teacher's pedagogy influences the equity concept in science education? 
- To what extent the equity gap of rural education meets the standard of science education?

\section{Methodology}

The study was carried out using a systematic review. One of the methods used was PRISMA Flow Diagram. This design was selected because it consisted of 27 checklist items and 4 phase flow diagrams. This diagram has four principal protocols that have to be followed; identification, screening, eligibility and included.

\subsection{PRISMA Flow Diagram}

\subsubsection{Identification}

In this phase, three databases were used to search for the articles; Google Scholar, Education Resources Information Center (ERIC) and SAGE journals. Keyword like "Pedagogical AND science education in Rural Schools" was used to search for the related articles. Inclusive and exclusive criteria were applied too in the process of searching for the articles. The criteria are:

1) The issue of science education in rural schools.

2) Pedagogical issue in science education in rural schools.

3) Equity issue in science education in rural schools.

4) Articles are within the 10 years.

5) Using references from the articles to search for suitable articles.

6) Using symbols like +, -, AND, NOT STEM cell.

\subsubsection{Screening}

At this stage, it was estimated 5000 articles were found using these three databases. The second phase rejected an article with the same title and author from the databases. Only relevant articles were accepted. Hence, the researcher chose 10 empirical studies to discuss the impact of pedagogy in science education to be analyzed.

\subsubsection{Eligibility and Included}

At this stage, the researcher filled in authors' details, titles, research objectives, methodologies and findings of the study in a Table 1 form for comparing purposes. The table helps the researcher to find similarities and differences in the chosen articles.

\subsection{Quality Assessment Criteria}

The second process was using quality assessment criteria adapted from McDermott et al. (2004). This model was used to ensure the selected articles meet the six elements in research. Table 2 shows the criteria for choosing the article.

Articles that exceeded the criteria were analyzed too. Each article was graded as below: (Table 3 ).

\section{Finding}

Equity in science education is a global issue. There have been issues reported by 
Table 1. Ten empirical study articles that related to the criteria and objectives of the study.

\begin{tabular}{llll}
\hline \multirow{2}{*}{ Researcher/year } & \multicolumn{3}{c}{ Criteria and objectives of the study. } \\
\cline { 2 - 4 } & Topic & Objective & Finding
\end{tabular}

Teacher beliefs and attitudes

Ramnarain \& about inquiry-based learning

Hlatswayo, 2018 in a rural school district in South Africa

COSEE-AK Ocean Science

Fairs: A Science Fair Model

Dublin et al., 2014 in Both Western Science and Traditional Native Knowledge
Agbo \& Isa, 2017

Scientific Skills and Concep Learning by Rural Women for Personal and National Development

Phronesis: Children's Local

Avery \& Kassam, 2011 Rural Knowledge of Science and Engineering

The Impact of Science

Alabdulkareem, 2016
To integrate western science education with traditional knowledge of Native and rural Alaska students in science education.
This study examines the concept of scientific skills in science education among rural women in national development.
The study found that teachers in rural schools have a To study that Teacher beliefs and positive attitude towards inquiry in science education attitudes about inquiry-based learning in a rural school and they find that inquiry-based learning can increase student motivation and help students understand more abstract science concepts.

The study found that learning outside the classroom such as learning integrates traditional and cultural knowledge relevant to science education is very effective and meaningful. This is because Native Alaska students and rural students find the traditional knowledge and culture of their daily lives to be related to science education. From the activities they participated in, they learned that their daily routines were related to science education. They gain a lot of experience in their activities especially in terms of communicating their science projects.

a) After science education was implemented among rural women the study found that scientific skills in science education among them showed significant improvement especially in health care, water use, nutrition, sanitation, and agriculture.

b) Based on these findings, researchers suggest that rural women should be provided with ample opportunity to study science and obtain quality education regardless of geographical, gender or socioeconomic background to meet the goals of science education equally and equally. It is in line with equity in science education.

a) 20 rural students learn various science and engineering concepts related to their daily lives.

This study analyzed video interviews and 407 pictures taken by 205 th and 6 th graders at a rural school in New York State. This study documents science education and engineering learning among them.

b) Students are found to be able to investigate and make explicit connections between what they learn in science class and what they learn outside of school in their local environment.

c) This finding is very important in implementing the process of teaching and learning science and engineering as it is closely related to the rural environment of student life

a) The results show a significant shift toward the discovery approach.

The goal of this study was to draw conclusions and pedagogical implications to contribute to a better understanding of science teachers' beliefs. b) The results show that there has been a shift in student-centered teaching methods to constructivism teaching among teachers in Saudi Arabia c) Teachers are found to be less confident in integrating science education with their cultural background. d) The results show that teachers see science as a separate issue and cannot easily link it to emerging cultural and historical issues. 


\section{Continued}

\begin{tabular}{|c|c|c|c|}
\hline Wills et al., 2014 & $\begin{array}{l}\text { Barriers to Student Success in } \\
\text { Madagascar }\end{array}$ & $\begin{array}{l}\text { a) Identify the effectiveness of } \\
\text { education among students } \\
\text { enrolled in science and } \\
\text { mathematics programs in } \\
\text { primary, secondary, and } \\
\text { university institutions. }\end{array}$ & $\begin{array}{l}\text { The study found that too many students in one class, } \\
\text { limited teaching and learning resources, and teacher } \\
\text { communication in high schools and universities were } \\
\text { more likely to use French in science education as a } \\
\text { hindrance to student achievement. This is very different } \\
\text { from students in urban schools and private institutions. }\end{array}$ \\
\hline Lee et al., 2018 & $\begin{array}{l}\text { Case study: Value-added } \\
\text { benefit of distance-based } \\
\text { instructional coaching on } \\
\text { science teachers' inquiry } \\
\text { instruction in rural schools. }\end{array}$ & $\begin{array}{l}\text { This study was conducted to } \\
\text { study the effectiveness of rural } \\
\text { teacher professional development } \\
\text { with Distance-based instructional } \\
\text { coaching (DBIC) in terms of } \\
\text { self-efficacy, and classroom } \\
\text { practice of a guided science } \\
\text { inquiry instructional approach. }\end{array}$ & $\begin{array}{l}\text { The findings show that the effectiveness of the processes } \\
\text { and technologies used for Distance-based instructional } \\
\text { coaching (DBIC) in the professional development (PD) } \\
\text { of teachers in rural schools have been successful in } \\
\text { improving science education programs among teachers, } \\
\text { providing support and guidance to teachers and assisting } \\
\text { teachers in terms of PD planning. The program will help } \\
\text { rural teachers further strengthen their teaching and } \\
\text { learning processes in delivering quality and equitable } \\
\text { science education to meet the concept of equity for rural } \\
\text { students. }\end{array}$ \\
\hline Schabort et al., 2018 & $\begin{array}{l}\text { From contextual frustrations to } \\
\text { classroom transformations: } \\
\text { female empowerment through } \\
\text { science education in rural } \\
\text { South Africa. }\end{array}$ & $\begin{array}{l}\text { The objectives of this research } \\
\text { project are to explore and } \\
\text { develop sustainable ways to } \\
\text { empower women to study science } \\
\text { education in rural schools in } \\
\text { South Africa. }\end{array}$ & $\begin{array}{l}\text { The findings of the study show that community } \\
\text { cooperation towards transforming classrooms in a rural } \\
\text { school can enhance the involvement of women in } \\
\text { science education. This will meet the demands of an } \\
\text { equity concept that seeks quality, fair and equitable } \\
\text { science education regardless of geographical, gender } \\
\text { and socioeconomic status. }\end{array}$ \\
\hline Kalonde, 2017 & $\begin{array}{l}\text { Rural school math and science } \\
\text { teachers' technology } \\
\text { integration familiarization }\end{array}$ & $\begin{array}{l}\text { a) This research explores the } \\
\text { importance of integrating } \\
\text { technology and Professional } \\
\text { Development (PD) to rural } \\
\text { secondary school teachers } \\
\text { b) Identify opportunities for } \\
\text { technology skills for rural } \\
\text { secondary schools in science and } \\
\text { mathematics learning Africa. }\end{array}$ & $\begin{array}{l}\text { a) The survey results show that there is a need for the PD } \\
\text { to familiarize rural teachers with the latest educational } \\
\text { technology. } \\
\text { b) The findings also show that teachers want to use ICT } \\
\text { equipment in the context of the lack of ICT equipment in } \\
\text { their schools. } \\
\text { c) Findings also indicate that teachers in rural schools } \\
\text { lack knowledge and exposure to the use of today's ICT } \\
\text { equipment. }\end{array}$ \\
\hline Veloo et al., 2013 & $\begin{array}{l}\text { Inquiry-based instruction, } \\
\text { students'attitudes, and } \\
\text { teachers' support towards } \\
\text { science achievement in rural } \\
\text { primary schools }\end{array}$ & $\begin{array}{l}\text { The purpose of this study is to } \\
\text { seek the relationship between } \\
\text { inquiry-based instruction, } \\
\text { students' attitudes toward science } \\
\text { and teachers' support towards } \\
\text { science achievement. It also looks } \\
\text { at the gender differences in } \\
\text { science achievement. }\end{array}$ & $\begin{array}{l}\text { The regression results revealed that all three independent } \\
\text { variables, namely inquiry-based instruction, students' } \\
\text { attitudes toward science and teachers' support } \\
\text { significantly influence science achievement among year } \\
\text { five students. }\end{array}$ \\
\hline
\end{tabular}

other researchers since 2010. This article only focuses on four domains like the main issue, limitation, year of publication and number of issues reported by researchers. These data are shown below: (Table 4).

\section{Code}

Only 10 articles were analyzed and went through a systematic review process 
Table 2. The six elements in research.

\begin{tabular}{|c|c|c|}
\hline No. & Elemen & Description \\
\hline 1 & Aim and objective & Does the article have a clear aim and objective? \\
\hline 2 & Scope & Does the article explain well how the research was developed, carried out and completed? \\
\hline 3 & Sample & Does the article provide an adequate sample? \\
\hline 4 & Methodology & $\begin{array}{l}\text { Does the report provide an adequate description of the methods used in the study like framework, data } \\
\text { collection, and analysis? }\end{array}$ \\
\hline 5 & Data & $\begin{array}{l}\text { Does the report provide sufficient data? Could a clear path be identified between the data and interpreta- } \\
\text { tion? }\end{array}$ \\
\hline 6 & Validated findings & $\begin{array}{l}\text { Have the researchers undertaken member checking, provided opportunities for feedback or other me- } \\
\text { chanism that would strengthen the validity of the analysis? }\end{array}$ \\
\hline
\end{tabular}

Table 3. Quality assessment of the rated articles based on grading A, B, C, and D.

\begin{tabular}{|c|c|c|c|c|c|c|c|c|}
\hline \multirow[b]{2}{*}{ Researcher } & \multirow[b]{2}{*}{ Year } & \multicolumn{6}{|c|}{ Criteria } & \multirow[b]{2}{*}{ Grade } \\
\hline & & $\begin{array}{l}\text { Objective and } \\
\text { goals }\end{array}$ & Study context & Sampling & Methodology & Data & $\begin{array}{l}\text { The results of the } \\
\text { study are validated }\end{array}$ & \\
\hline $\begin{array}{c}\text { Ramnarain \& } \\
\text { Hlatswayo }\end{array}$ & 2018 & I & I & I & I & I & I & A \\
\hline Dublin et al. & 2014 & I & I & I & I & I & I & A \\
\hline Agbo \& Isa & 2017 & I & I & I & I & I & I & A \\
\hline Avery \& Kassam & 2011 & I & I & I & I & I & I & A \\
\hline Alabdulkareem & 2016 & I & l & l & I & l & I & A \\
\hline Wills et al. & 2014 & I & I & I & I & I & I & A \\
\hline Lee et al. & 2018 & I & I & I & I & I & I & A \\
\hline Schabort et al. & 2018 & I & I & I & I & I & I & A \\
\hline Kalonde & 2017 & I & I & I & I & I & I & A \\
\hline Veloo et al. & 2013 & I & I & I & I & I & I & A \\
\hline
\end{tabular}

\begin{tabular}{cc}
\hline Grade & Details \\
\hline A & Meet six criteria \\
B & Meet five criteria \\
C & Meet four criteria \\
D & Meet three criteria \\
\hline
\end{tabular}

because they meet the criteria set in the diagram and model. Code was used to indicate each category. 1) represents a well-planned curriculum set by the school. 2) represents teaching aids and resources used by teachers. 30 refers to teachers' understanding of the subject matter. 4) represents teachers' content knowledge on science subject. 5) refers to teachers' effectiveness in lesson delivery. 6) refers to pedagogy in which teacher has to be able to find suitable 
Table 4. The criteria issue set in the 10 articles.

\begin{tabular}{|c|c|c|c|c|c|c|c|c|c|c|c|c|}
\hline & \multirow{2}{*}{ Researcher/Year } & \multirow{2}{*}{ Year } & \multirow{2}{*}{ Journal } & \multirow{2}{*}{ Methodology } & \multicolumn{8}{|c|}{ Code and issue } \\
\hline & & & & & 1 & 2 & 3 & 4 & 5 & 6 & 7 & 8 \\
\hline 1. & Ramnarain \& Hlatswayo & 2018 & $\begin{array}{l}\text { South African Journal } \\
\text { of Education }\end{array}$ & Mixed method & & 1 & & & & 1 & & I \\
\hline 2. & Dublin et al. & 2014 & $\begin{array}{l}\text { Journal of Geoscience } \\
\text { Education }\end{array}$ & Qualitative research & l & & I & & & l & & \\
\hline 3. & Agbo \& Isa & 2017 & $\begin{array}{l}\text { Science Education } \\
\text { International }\end{array}$ & quasi-experimental & & & & & & 1 & l & \\
\hline 4. & Avery \& Kassam & 2011 & $\begin{array}{l}\text { Journal of Research in } \\
\text { Rural Education }\end{array}$ & Descriptive research & l & l & & & / & l & & \\
\hline 5. & Alabdulkareem & 2016 & $\begin{array}{l}\text { Journal of Education } \\
\text { and Learning }\end{array}$ & Qualitative research & & & I & & & l & & \\
\hline 6. & Wills et al. & 2014 & Case study & Qualitative research & & 1 & & & & l & & \\
\hline 7. & Lee et al. & 2018 & $\begin{array}{l}\text { Journal of Science Teacher } \\
\text { Education, } 29 \text { (3), 179-199. }\end{array}$ & Case study & & & I & l & & 1 & & \\
\hline 8. & Schabort et al. & 2018 & $\begin{array}{l}\text { Educational Action Re- } \\
\text { search, } 26(1), 127-143 \text {. }\end{array}$ & Qualitative Research & & & & & & l & & \\
\hline 9. & Kalonde & 2017 & $\begin{array}{l}\text { International Journal of } \\
\text { Educational Technology }\end{array}$ & $\begin{array}{l}\text { This study uses a } \\
\text { concurrent exploratory } \\
\text { mixed-method to collect } \\
\text { and analyze data. }\end{array}$ & & 1 & & 1 & & 1 & & \\
\hline 10. & Veloo et al. & 2013 & $\begin{array}{l}\text { Conference on Learning, } \\
\text { Teaching and Educational } \\
\text { Leadership }\end{array}$ & $\begin{array}{l}\text { Quantitative } \\
\text { Research }\end{array}$ & & l & & & I & I & l & \\
\hline
\end{tabular}

methods to be used in teaching. 7) is for teacher evaluation that includes summative or formative assessments. 8) refers to teacher's constraints in teaching and learning.

\section{Discussion}

To address the research questions, there are eight key issues to be discussed namely curriculum issues, materials, and resources, teacher knowledge, teacher understanding, self-efficacy, pedagogical methods, assessment and time.

\subsection{Curriculum}

Findings from the empirical study of Dublin et al. (2014) implemented a curriculum with rural Alaska Native students in science practices related to the culture and community of Native Alaska students where students have a strong positive feeling towards themselves in science education and are comfortable with being identified as scientists. Avery \& Kassam (2011) implemented their curriculum at rural New York schools. The findings showed 20 children studying various concepts of science and engineering participated in activities related to their daily lives. Researchers found students directly investigating, made explicit relationships between what they learned outside school in their local envi- 
ronment with what they learned in science classes. These discoveries signal the teaching and learning process of science and engineering can be interconnected with their surroundings. The above research shows that science education in rural schools can meet the demands of equity concepts where quality education can be delivered to all regardless of geography, gender or socioeconomic background.

\subsection{Material and Resources}

Teaching materials are all types of materials used to assist teachers in teaching and learning activities. While the resources in the context of this discussion are teaching and learning resources that are stored in a variety of media and can assist students in learning as a curriculum embodiment. This resource is unlimited and in many forms such as print, video, software or a combination of various formats that students and teachers can use. According to the findings of Nasri et al. (2010), the aspect of school facilities and science labs that are lacking and incomplete will limit the process of teaching and learning science in schools. Limited materials and resources in science learning can be seen as an obstacle for rural students to get equal rights in quality science education. This statement is supported by Ramnarain \& Hlatswayo (2018) who also stated in his findings that teachers claimed to face difficulty implementing research-based learning due to lack of lab facilities and teaching aids. In the study of Wills et al. (2014) also stated the same thing and pointed crowded class and limited resources such as infrastructure often become a stumbling block for teachers in rural schools in Madagascar. This indirectly led to poor academic performance by Madagascan students.

\subsection{Teacher's Understanding}

In the context of rural science education, teachers' understanding of science education is very meaningful. This is because teachers are the main sources for students in rural schools. Teachers "understanding will impact teachers" pedagogy. Alabdulkareem (2016) finds that teachers' weakness in integrating science education in rural schools in Saudi is that teachers saw science as a separate issue and could not easily link it with cultural and historical issues.

\subsection{Teacher Knowledge}

Knowledge means everything that is known or learned about science (Dictionary of the 4th edition of the Board). Therefore, teachers' knowledge should be holistic, especially those who teach in rural schools. In a recent study by Holubova (2008) teachers need to understand the content of science education in detail as it can help teachers determine appropriate and effective science teaching strategies during the teaching session. Effective teaching strategies make it easier for students to understand what they are learning. The findings of the study conducted by Osman et al. (2006) show that science teachers as a whole need sup- 
port in upgrading their knowledge and skills in science subjects.

\subsection{Teacher's Effectiveness}

The findings show that the effectiveness of teachers in pedagogical methods provides significant pedagogical impact to rural school students. Veloo et al. (2013) found that the positive attitude of teachers and students in learning science significantly influenced the achievement of science in rural schools in Kedah, Malaysia. In this regard, the effectiveness of the teacher also requires the teacher's discretion in selecting the pedagogical method used. The findings from Avery \& Kassam (2011) found pedagogy was conducted in their daily living environment. It also revealed that students could investigate directly and made explicit relationships with what they learned outside the school in their local environment with what they learned in science classes.

\subsection{Teacher Pedagogy}

Overall, the findings show that pedagogy has a great impact on rural schools. This statement is evident from the findings by Ramnarain \& Hlatswayo (2018) that school teachers from rural areas had a positive attitude towards research in teaching and learning of Physical Sciences, and recognizing research benefits, such as overcoming student motivation and supporting students in understanding the concepts of abstract science. On the other hand, Avery \& Kassam (2011) proved teacher's pedagogy should be interlinked with the environment where students live. In their study, it was found that 20 children learned various science and engineering concepts by participating in activities related to their daily lives. Students could directly investigate and made explicit relationships between what they learned outside of school with what they learned in science classes. This demonstrates the pedagogical impact can influence teachers' pedagogy in science learning. Furthermore, there is a study on pedagogical impact on rural women. The findings of Agbo \& Isa (2017) prove that women should be allowed to explore science to produce maximum productivity in national development. This finding is supported by the findings from Veloo et al. (2013) that showed female students are more prominent in science learning than male students. Besides, interesting pedagogical methods as suggested by Dublin et al. (2014) are particularly relevant in learning. Project-based pedagogical methods make learning fun and students feel valued. Accordingly, a study by Osman et al. (2006) stated that teachers' concern about the importance of improving teaching methods can make their teaching more meaningful and engaging and will lead to improvement in student achievement in the lesson.

\subsection{Assessment}

Assessment is a method of measuring a student's mastery level in education. According to the study of Mahmud et al. (2018) science teachers need to be 
equipped with knowledge, understanding, and practice of high-level thinking skills including developing high-level questions in their assessment, establishing rubrics in assessing their student activities and evaluating project-based science activities. The findings of Veloo et al. (2013) found that the positive attitude of teachers and students in science learning significantly influenced the achievement of science in rural schools in the interior of Kedah, Malaysia. Whereas Agbo \& Isa (2017) found that rural women showed significant improvements in their skills and knowledge in healthcare, water use, nutrition care, sanitation, and agriculture. These findings suggest that rural women should be given the right to learn science education for the sake of maximum productivity, self, and national development.

\subsection{Time}

The empirical study done by Ramnarain \& Hlatswayo (2018) shows teachers are less likely to make research-based learning in their studies. This is because of the time constraint as they have to complete the syllabus.

\section{Conclusion}

In this globalization era, greater emphasis has been put in studying science. Many empirical findings and studies state that rural children and women if given equal access to quality education will be able to learn various science concepts in their daily lives. This statement is in line with the study conducted by Oriahi et al. (2010) that teaching and learning science in school enhances students' understanding of the world around them and they can acquire appropriate skills and knowledge that enable them to survive and make contribution to the society. However, this is only achievable if the teachers implement the right pedagogy, especially teachers serving in rural schools.

Quality education comes from quality pedagogy and achieved learning objectives. From this systematic review, it can be said that rural school education has not met the science education standard. This can be seen from the lack of technology as a teaching aid and rural school teachers have minimal knowledge of the current technology (Kalonde, 2017). Besides, lack of infrastructure such as laboratory facilities and small classroom contribute to the problem in teachers' pedagogy (Ramnarain \& Hlatswayo, 2018).

Therefore, educators have to play a role in bringing the best education to their students regardless of their geographical factor. The concept of equity in education can be achieved if the community has enough manpower and financial resources to help rural communities receive quality education. This indeed will meet the education standard.

\section{Acknowledgements}

This research was partially supported by a grant received from the Faculty of 
Education Universiti Kebangsaan Malaysia PP-FPEND-2019.

\section{Conflicts of Interest}

The authors declare no conflicts of interest regarding the publication of this paper.

\section{References}

Agbo, F. O., \& Isa, A. A. M. (2017). Scientific Skills and Concept Learning by Rural Women for Personal and National Development. Science Education International, 28, 128-135.

Alabdulkareem, S. A. (2016). The Impact of Science Teachers' Beliefs on Teaching Science: The Case of Saudi Science Teachers. Journal of Education and Learning, 5, 233-249. https://doi.org/10.5539/jel.v5n2p233

Avery, L. M., \& Kassam, K. A. (2011). Phronesis: Children's Local Rural Knowledge of Science and Engineering. Journal of Research in Rural Education (Online), 26, 1.

Blatchford, P., Baines, E., Rubie-Davies, C., Bassett, P., \& Chowne, A. (2006). The Effect of a New Approach to Group Work on Pupil-Pupil and Teacher-Pupil Interactions. Journal of Educational Psychology, 98, 750. https://doi.org/10.1037/0022-0663.98.4.750

Caleon, I. S., \& Subramaniam, R. (2008). Attitudes towards Science of Intellectually Gifted and Mainstream Upper Primary Students in Singapore. Journal of Research in Science Teaching: The Official Journal of the National Association for Research in Science Teaching, 45, 940-954. https://doi.org/10.1002/tea.20250

Cooper, M. M. (2015). Why Ask Why? Journal of Chemical Education, 92, 1273-1279. https://doi.org/10.1021/acs.jchemed.5b00203

Dewan, B. P. (2005). Kamus Dewan Bahasa dan Pustaka Edisi ke empat. Kuala Lumpur.

Dublin, R., Sigman, M., Anderson, A., Barnhardt, R., \& Topkok, S. A. (2014). COSEE-AK Ocean Science Fairs: A Science Fair Model That Grounds Student Projects in Both Western Science and Traditional Native Knowledge. Journal of Geoscience Education, 62, 166-176. https://doi.org/10.5408/12-411.1

Good, T. L., \& Lavigne, A. L. (2017). Looking in Classrooms. Abingdon-on-Thames: Routledge. https://doi.org/10.4324/9781315627519

Holbrook, J. (2010). Education through Science as a Motivational Innovation for Science Education for All. Science Education International, 21, 80-91.

Holubova, R. (2008). Effective Teaching Methods-Project-Based Learning in Physics. Online Submission, 5, 27-36. https://www.oecd.org/pisa/pisa-2015-results-in-focus.pdf

Kalonde, G. (2017). Rural School Math and Science Teachers' Technology Integration Familiarization. International Journal of Educational Technology, 4, 17-25.

Kementerian Pendidikan Malaysia (2015). Panduan Pengurusan Mata Pelajaran Sains, Jemaah Nazir dan Jaminan Kualiti. Aras 3-6, Blok E15, Putrajaya: Kompleks Kerajaan Parcel EPusat Pentadbiran Kerajaan Persekutuan.

Lee, S. C., Nugent, G., Kunz, G. M., Houston, J., \& DeChenne-Peters, S. (2018). Case Study: Value-Added Benefit of Distance-Based Instructional Coaching on Science Teachers' Inquiry Instruction in Rural Schools. Journal of Science Teacher Education, 29, 179-199. https://doi.org/10.1080/1046560X.2018.1432226

Mahmud, S. N. D., Nasri, N. M., Samsudin, M. A., \& Halim, L. (2018). Science Teacher Education in Malaysia: Challenges and Way Forward. Asia-Pacific Science Education, 4, 8. https://doi.org/10.1186/s41029-018-0026-3 
McDermott, E., Graham, H., \& Hamilton, V. (2004). Experiences of Being a Teenage Mother in the UK: A Report of a Systematic Review of Qualitative Studies. Lancaster: Lancaster University.

Nasri, N. M., Yusof, Z. M., \& Halim, L. (2010). Uncovering Problems Faced by Science Teacher. Procedia-Social and Behavioral Sciences, 9, 670-673.

https://doi.org/10.1016/j.sbspro.2010.12.215

OECD (2012). Equity and Quality in Education: Supporting Disadvantaged Students and Schools. Paris: OECD Publishing.

OECD (2018). PISA 2015 Results in Focus. OECD Publishing. https://www.oecd.org/pisa/pisa-2015-results-in-focus.pdf

Oriahi, C. I., Uhumuavbi, P. O., \& Aguele, L. I. (2010). Choice of Science and Technology Subjects among Secondary School Students. Journal of Social Sciences, 22, 191-198. https://doi.org/10.1080/09718923.2010.11892801

Ramnarain, U., \& Hlatswayo, M. (2018). Teacher Beliefs and Attitudes about InquiryBased Learning in a Rural School District in South Africa. South African Journal of Education, 38, 1-10. https://doi.org/10.15700/saje.v38n1a1431

Rashid, S. M. R. A. (2008). Peluang dan Cabaran Pendidikan dalam Kalangan Masyarakat Luar Bandar: Satu Kajian Kes Isi Rumah Melayu Miskin di Jajahan Bachok Kelantan. Kelantan: Universiti Sains Malaysia.

Schabort, F., Sinnes, A., \& Kyle Jr., W. C. (2018). From Contextual Frustrations to Classroom Transformations: Female Empowerment through Science Education in Rural South Africa. Educational Action Research, 26, 127-143.

https://doi.org/10.1080/09650792.2017.1286996

Veloo, A., Perumal, S., \& Vikneswary, R. (2013). Inquiry-Based Instruction, Students' Attitudes, and Teachers' Support towards Science Achievement in Rural Primary Schools. Procedia-Social and Behavioral Sciences, 93, 65-69. https://doi.org/10.1016/j.sbspro.2013.09.153

Wills, A. R., Reuter, K. E., Gudiel, A. A., Hessert, B. P., \& Sewall, B. J. (2014). Barriers to Student Success in Madagascar. Global Education Review, 1, 114-134. 